\title{
From Lessons Learned the Hard Way to Lessons Learned the Harder Way
}

\author{
Andria Foote Schwegler, PhD \\ Assistant Professor, Department of Psychology and Counseling \\ Texas A\&M University - Central Texas
}

My departure from traditional methods of teaching and assessment (i.e., lecture and close-ended exams) was prompted years ago by a "gut feeling" that has morphed into an explicit examination of my teaching practice and students' reactions to it.

The scholarly approach and empirical evidence in "Teachers and Learning" (Hutchings, Huber \& Ciccone, 2011, Chapter 2) provided me with the scientific and social support I needed to publically challenge existing norms regarding teaching practices, reevaluate my data collection efforts, and advocate for change based on

best practices, not on tradition, both inside my classroom and beyond.

So there I was, less than a year into my first assistant professor position, teaching on a July afternoon in a poorly vented classroom in Texas. I was deeply involved in an animated lecture about an event I had experienced as a public school teacher that beautifully demonstrated a concept for the Educational Psychology course I was teaching, when a student in the front row looked at her watch. At that moment, I questioned everything I knew about teaching.

I froze mid-sentence and stared in disbelief at the students in the room. How could they consider checking the time in the midst of my thoroughlyresearched, well-crafted example? How could they be distracted by hunger or heat in the room with such an excellent example of faculty engagement, enthusiasm, and preparation before them? How could they be anticipating the end of class, just 20 minutes away, when there was still so much academic ground to cover?

At that moment I realized that I was the hardest working person in the room, and ironically, the only one who already knew the material. Staring at my class, I knew that I was the only one paid to be there, and logic would dictate that if I am paid to do a job, I should work. But that notion did not ease my confusion. After all, learning is effortful; it requires work. So why were my students not working? I was working as hard as I could at teaching. Why were they not working hard at learning? I mentally compared what I was doing at that moment to how I was taught: dry erase marker, lecture, text and test relevance, real-world application, content expertise. All checked out. So I still could not figure out why my student had looked at her watch, until I realized that I had done the same as an undergraduate student.

The creeping realization that my students were marking time until class was over, just as I had done, made the heat in the room intense. Slowly, it dawned on me that my students were not working because I was not making them work. I was doing it all. Then I realized that my graduate school experiences provided no solutions to the problem that resulted in 25 pairs of eyes bearing quizzically down on me as my students wondered why I had stopped talking for so I-o-n-g. I returned their glassy-eyed, confused stare as I contemplated that tree falling in the forest... If I am teaching in a classroom, but students are not learning, am I really teaching?

Suddenly, being a teacher became less about teaching and more about student learning. Despite all my hard work, preparation, and good intentions, I had missed the mark. Because I had no immediate solution for how to proceed, I abruptly wrapped up class to finish my existential crisis in the privacy of my office. In the silence, I heard unquestioned assumptions and well-intended advice about teaching from my graduate school days rattling off in my head: "Never admit that you do not know the answer." "Do not smile until mid-term." "Take attendance or 
no one will come to class." "Use scantrons so the machine will grade it for you." Nothing helped. I could not see why I was having student attention problems in the higher education classroom, when I did not have these problems in the elementary classrooms of my "former life" (i.e., the one before graduate school). Of course, that was a different world. When teaching children, I quickly discovered that I must keep the children actively involved in learning activities and allow them some freedom to pursue their interests, or they will become actively involved in every form of misbehavior imaginable. But university classes just were not conducted in this manner. "If only they were...," I thought.

Thus began my journey into nonconformity. Starting out, I implemented those lessons that I learned the hard way, when the student looked at her watch. I transferred some of the workload I had previously shouldered myself to my students. This shift was not well received. Students who had been taught throughout their college careers to depend on the teacher to direct learning, resisted peer input that shaped class content, and were disgruntled when passive listening and sporadic note taking were replaced with more effortful activities requiring active participation. I was not persuaded by the complaints though, because I felt empowered by the physical evidence of students' learning. Instead of viewing the stacks as simply papers to grade, I saw them as valuable feedback that reflected students' understandings and confusions. Through this feedback-revision process, I had devised a way to improve student learning, helping me withstand their resistance.

Unfortunately, social support for my changes remained sparse until I read The Scholarship of Teaching and Learning Reconsidered: Institutional Integration and Impact. As a result of their research, Hutchings, Huber, and Ciccone (2011) acknowledge that 'leaders and participants in efforts to improve students' educational experiences and outcomes often feel they are working against the grain" (p. 6). This statement accurately summarized my early experiences. But, having read Hutchings et al. (2011), I am now crafting a new understanding of the modifications I have made to my teaching techniques that aim to improve student learning. The scientific and social support provided in the text allows me to publically challenge existing norms regarding teaching practices and advocate for change based on best practices, not tradition, both within the boundaries of my classroom and beyond: an arguably daring move for an untenured faculty member in a tenure-track position.

\section{Applying Discipline-Specific Knowledge to Teaching and Learning}

Considering the scholarship of teaching and learning as "the intellectual work that faculty do when they use their disciplinary knowledge to investigate a question about their students' learning" (Dewar, 2008, p. 18), I am now more explicitly viewing my teaching role from my discipline of social psychology, and critically examining how I can use what I know there to improve teaching and learning. When viewed as a social influence process, empirically based research findings regarding group influence can be applied to teaching with useful results.

Connecting the social influence literature to teaching, current methods of classroom instruction can be viewed from a social norms perspective. Reno, Cialdini, and Kallgren (1993) distinguish between descriptive and injunctive norms. Descriptive norms are those that provide information about how most people behave, and this information suggests how we should behave. Considering teaching, the oldest and still most widely used technique in university classrooms is lecture (Svinicki \& McKeachie, 2011, p. 55). Thus the descriptive norm indicates that university professors teach via lecture. Many faculty members may use lecture, thinking it is the appropriate technique, while dismissing counter-normative methods, just as I did when first starting out in higher education. While initially creating my new identity as a university faculty member, I now realize that I was conforming to the descriptive norm I repeatedly experienced in graduate school. Perhaps realizing that descriptive norms merely indicate what people do, regardless 
of whether this is most effective, may help faculty reexamine their own behavior and confront these subtle pressures to conform.

More difficult to address, however, are the social pressures exerted by injunctive norms. These are distinguished from descriptive norms by their element of perceived social pressure, indicating what people should do and carrying the weight of social approval or social sanctions (Reno et al., 1993). These norms are made salient when others comment on our teaching practices, especially when these differ from their own practices. My students' complaints after I shifted their workload from passive listening to active writing indicated their disapproval and removal of social support for my actions.

Such social pressure is difficult to withstand, especially when it comes from one's colleagues and supervisors. Though no one would balk at my goal to improve student learning, colleagues are quick to comment on the amount of work I require of my students and myself toward this end. For example, during my presentation at a recent faculty brown bag, my colleagues appeared quite alarmed at the numerous moderated discussion forums I required in an online course and recommended that I consider doing something else. These comments clearly indicated their disapproval of what they initially perceived as a work-intensive technique. Such social sanctions, when coming from groups that we value (i.e., referent groups), exert a powerful influence on our behavior and tend to shift it in the direction preferred by the group (Reno et al., 1993). However, by maintaining a focus on other group norms that support our actions, we can withstand this influence (Kallgren Reno, \& Cialdini, 2000). So, as I explained how I used the moderation tool to keep students' submissions hidden until the due date and that this strategy reduced repetition of content and led to more original responses, I thought of the scholars described by Hutchings et al. (2011) who have made much more substantial contributions to student learning. In their eyes, my technique would be status quo, and thinking of this referent group allowed me to face public social disapproval of my tried-and-true teaching technique with confidence and with the patience of a teacher who is welcoming a new set of learners.

Since reading "Teachers and Learning" and applying my discipline-specific knowledge to rethink how I approach teaching, no longer do the same descriptive and injunctive norms prompt my conformity. Instead of looking to tradition and typical behavior (i.e., descriptive norms), I have a more clearly articulated rationale for seeking out empirical evidence to substantiate my teaching techniques, and I am taking a more vocal and direct approach to revise existing injunctive norms for how teaching in the higher education setting should be conducted.

\section{Making Learning Visible through Students' Active Participation}

After the shock of the student looking at her watch wore off, one of my early, angry, gut-level reactions to solving the problem was to simply keep the students so busy that they would not have time to look at their watches. Though initially brash, with some tweaking, this turned out to be a really good idea.

Quietly listening to lectures, taking sporadic notes, and asking for an occasional clarification did not provide me with any solid evidence that my students were learning, but it was not until I started teaching online that I had this realization. In preparing for my first fully online course, I was daunted by the fact that I had absolutely no surveillance of my students. Outside of exams and a paper assignment, I had no way to determine if students were reading the materials, taking notes, thinking critically, or doing anything except clicking links in the learning management system. In planning my weekly lessons, I felt as though my ability to monitor student learning in progress had been stripped from my possession. I wanted to retreat to the certainty I felt in my face-to-face courses.

Instead of retreat, my solution to achieving visibility of student learning online was to create a series of recurrent, weekly assignments. I intentionally crafted and sequenced these assignments, requiring students to dig progressively 
deeper into course content. Assignments early in the week required comprehension-level paraphrases of important course concepts, providing the foundation for later application of these concepts to personal examples or homework problems. Finally, the unit concluded with analysis and synthesis of concepts in the end-of-the-week essays. This need to "see" student learning in the absence of being able to "see students learning" catapulted my online students into active participation in course content. Such active participation in learning is unfamiliar to most students and requires them to formulate new approaches to coursework (Dringus, 2000).

This shift in teaching strategy provided me with evidence of my students' learning that I never had before. Examining these assignments, I realized that in my face-to-face courses I had few ways to determine if my students were reading the materials, taking notes, thinking critically, or doing anything except making eye contact, nodding, writing unknown content in notebooks, and replying to questions (which, in retrospect, totaled less than one question per class period per student). Certainly, these students' behaviors are reassuring during lecture, but while reading "Teachers and Learning," I was prompted to critically examine this data and ask, "Are these classroom behaviors valid operational definitions of student learning?" As a researcher, had I begun to read a research article with such a loose set of behaviors to operationally define a dependent variable, I would have tossed the article into the recycle bin without further consideration. So, as a teacher, given the same information, why did I feel assured that my students were learning?

The certainty that my students were learning based on my ability to see them in my face-to-face courses crumbled. No longer would I rely on my assumptions and residual positive feelings from interactions with students to convince myself that they were learning. Now, I require that all students, whether online or face-to-face, be active participants by producing and submitting evidence of their learning. I appear to be in good company. Hutchings et al. (2011) admit, "...most of the faculty who have been drawn to the scholarship of teaching and learning have also been drawn to pedagogies that actively engage students" ( $p$. 28). I certainly understand why. If learning is not "visible" (p. 33), how can it be observed and measured? Having students create a product or demonstrate a relevant behavior provides evidence of learning (not merely evidence of polite manners during lecture) that can be measured, constructively criticized, and improved.

\section{Putting a Spin on the Webs of Change}

Working in my own classroom to examine and improve student learning has generated opportunities for me to collaborate with colleagues. Very quickly, casual small talk has turned into research projects involving other faculty in the department. For example, after discussing the chronic anxiety students feel toward statistics courses, my colleague and I questioned how we could reduce this anxiety and whether a reduction would lead to improved student learning. After crafting a manipulation to reduce anxiety born out of the attitude-change literature, we are currently collecting data to test our technique. Not only does this collaboration have the potential to remedy a shared problem, but also, after reading Hutchings et al. (2011), I now see beyond my classroom application and can view the larger relevance of this work.

I have come to realize that my research problems originate at the immediate intersection of teacher-learner-content within a particular course, but these proximal concerns may be manifestations of larger, more distal issues that need attention. So, instead of maintaining my current focus on generating data to solve immediate student learning needs in my individual courses, I now realize that I need to consider a broader view of my work. Perhaps the lessons I have learned through my feedback-revision processes with my students are more widely valuable than they are currently being used. Leaving the traditional model of teaching as a "private, often isolated" profession, the social support I have found in "Teachers and 
Learning" has enabled me to see a larger audience for my data (Hutchings et al., 2011 , p. 35). I have just begun to critically examine its utility to inform issues beyond my classroom.

This new view informs not only my work as a teaching faculty member but also my role as an online coordinator, in which I mentor and facilitate faculty members' efforts to improve teaching effectiveness online. As part of this role, I coordinate peer reviews of online courses and am building working relationships with faculty outside of my department. Serving on these peer reviews has provided a broader group of professionals with diverse perspectives and applications of content with whom to exchange ideas and discuss teaching techniques. This dialogue is creating avenues for interdisciplinary collaboration and validates shared desires to improve learning. Through discovering these shared connections, new groups of individuals are revising injunctive norms regarding what constitutes effective teaching, and these new norms are beginning their creep forward to affect larger-scale normative change.

Supporting this effort, my institution's distance learning office is emerging as a hub for faculty who are interested in holding larger-scale conversations about improving teaching and student learning. Launching distance learning into this role was the addition of required training for faculty who teach online, accompanied by voluntary participation in the peer review process. Word-of-mouth information about the trainings and peer reviews spread rapidly, and faculty members began talking about teaching, both online and face-to-face, in ways not previously heard. Though some faculty members attacked these policies, others saw them as formalized attempts to improve teaching, a process in which they were interested. To contextualize this interest, I leveraged my understanding of The Scholarship of Teaching and Learning Reconsidered. For example, to recruit faculty to participate in our first brown bag on improving instruction using online tools, I sent an email after a week of low registration rates to the faculty in my school, citing Hutchings et al. (2011) and couching the meeting from a "perspective of growth" and explaining it as a "bottom-up" initiative by faculty who share the common goal of teaching students more effectively. Registration rates for the session increased the following day by $500 \%$. Though the actual frequency of registrants from my school grew from only 0 to 5 , linking the meeting to its broader context was favorably received.

And, the momentum is continuing. My institution is currently revising our definition of scholarship to explicitly recognize the scholarship of teaching as legitimate faculty work. I take every opportunity to publically support this revision. And, I use my growing understanding of the scholarship of teaching and learning to craft new ways to approach naysayers to this change. For example, when a colleague told me that conducting research on teaching was "too easy" and dismissed its value, I requested that he show me his data, claiming that I did not find it easy and that he could teach me how it is done. When he admitted that he had no data, only years of experience, I pressed him for an explanation of why he thought research on teaching was easy, whereas research on other topics was not (Macfarlane, 2011). He had none. I reminded him that though lessons learned the hard way through experience were personally poignant, lessons learned the harder way through research were more compelling (c.f. Grove \& Meehl, 1996), and I invited him to accompany me on my more illuminated journey of nonconformity.

Now, instead of feeling pressure to conform to tradition or feeling defensive when disagreement escalates to attack, alternative referent groups that include other scholars of teaching and learning can provide support when naysayers exert pressure. It is reassuring to know that I no longer have to face my existential crises about teaching and learning alone in my office. I am now seeking out colleagues and students to hash out ideas and strategies with me. I have new ideas to explore and new resources to which to turn for guidance when I am faced with these harder lessons. 


\section{References}

Dewar, J. M. (2008). An apology for the scholarship of teaching and learning. Insight: A J ournal of Scholarly Teaching, 3, 17-22.

Dringus, L. P. (2000). Towards active online learning: A dramatic shift in perspective for learners. The Internet and Higher Education, 2(4), 189-195.

Grove, W. M., \& Meehl, P. E. (1996). Comparative efficiency of informal (subjective, impressionistic) and formal (mechanical, algorithmic) prediction procedures: The clinicalstatistical controversy. Psychology, Public Policy and Law, 2, 293-323.

Hutchings, P., Huber, M. T., \& Ciccone, A. (2011). The scholarship of teaching and learning reconsidered: Institutional integration and impact. Stanford, CA: JosseyBass.
Kallgren, C. A., Reno, R. R, \& Cialdini, R. B. (2000). A focus theory of normative conduct: When norms do and do not affect behavior. Personality and Social Psychology Bulletin, 26, 1002-1012.

Macfarlane, B. (2011). Prizes, pedagogic research and teaching professors: Lowering the status of teaching and learning through bifurcation. Teaching in Higher Education, 16, 127-130.

Reno, R. R., Cialdini, R. B., \& Kallgren, C. A. (1993). The transsituational influence of social norms. Journal of Personality and Social Psychology, 64, 104-112.

Svinicki, M., \& McKeachie, W. J. (2011). McKeachie's teaching tips: Strategies, research, and theory for college and university teachers $\left(13^{\text {th }}\right.$ ed.). Belmont, CA: Wadsworth.

Dr Andria Foote Schwegler is an Assistant Professor of Psychology and the Online Coordinator for the School of Education at Texas A\&M University Central Texas. As the spouse of an active-duty Army soldier with multiple duty stations for over 23 years, her teaching experience is diverse, ranging from public preschool to graduate level statistics. In addition to questions regarding teaching and learning, her research interests include the effects of deployment on soldiers and military families. She is the mother of two rough-and-tumble, wonderful boys, JB (7 years) and JS (4 years). 